\title{
E-Waste Collection and Treatment Options: A Comparison of Approaches in Europe, China and Vietnam
}

\author{
Stefan Salhofer
}

\begin{abstract}
E-waste is a complex waste stream with several categories of products, each of them requiring a specific treatment technology. This chapter analyses the status quo of e-waste management in three global regions, where the European Union represents a frontrunner in environmental legislation and implementation; China, catching up with recent legislation and large-scale investments in recycling infrastructure; and Vietnam, as an example for the numerous countries where an unregulated situation dominates. This chapter aims at giving an overview of the management of this waste stream focussing on two relevant stages in the material recovery chain: collection as the interface between consumers and waste management and treatment with an overview of technologies applied for the removal of hazardous materials and the recovery of valuable materials such as steel, copper, plastics and others. Challenges for these situations are identified.
\end{abstract}

Keywords Collection, E-waste, Recycling, Source separation, Treatment

\section{Contents}

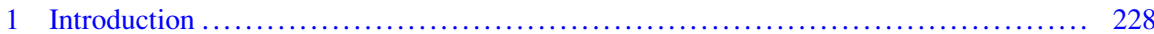

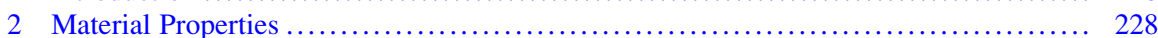

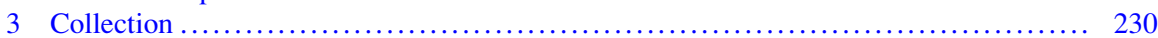

$3.1 \quad$ E-Waste Collection in Europe ........................................ 230

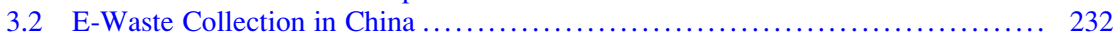

3.3 E-Waste Collection in Vietnam ................................ 233

\footnotetext{
S. Salhofer $(\bowtie)$

University of Natural Resources and Life Sciences, Vienna, Wien, Austria

e-mail: stefan.salhofer@boku.ac.at
} 


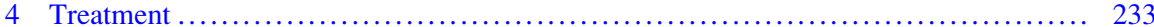

4.1 Treatment in Europe ................................................. 233

4.2 Treatment in China ............................................. 236

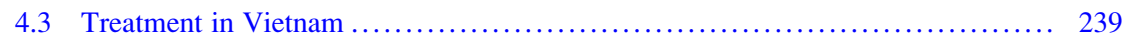

5 Conclusions .......................................................... 240

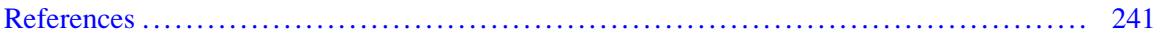

\section{Introduction}

End-of-life electrical and electronic equipment (here referred to as e-waste) is more complex than other waste streams in terms of material composition and the content of hazardous materials. On the input side of recycling processes, this waste stream consists of a number of product categories (e.g. ten categories in the WEEE I Directive 2002/96/EC) [1], which have rather different properties and need to be treated separately. Specifically, cooling and freezing equipment (containing CFCs in the coolant circuit and the insulation) requires a specific technology, and the same holds true for fluorescent lamps and screens.

In a global perspective, different levels of regulation have been established, stretching from unregulated situations in most of the low-income countries to comprehensive legislation, including the role of producers in Extended Producer Responsibility (EPR) schemes, mainly found in EU member states and some other countries. More details on EPR can be found at OECD [2].

This chapter aims at giving an overview of the management of this waste stream focussing on two relevant stages in the material recovery chain: collection as the interface between consumers and waste management and treatment with an overview of technologies applied for the removal of hazardous materials and the recovery of valuable materials such as steel, copper, plastics and others. To demonstrate differences and the wide range of e-waste management implementations, the situation in three global regions with different levels of development is analysed: the European Union as a frontrunner in environmental legislation and implementation; China, catching up with recent legislation and large-scale investments into recycling infrastructure; and Vietnam, as an example for the numerous countries where an unregulated situation dominates. Challenges arising from each of these situations have been identified.

\section{Material Properties}

E-waste, defined as 'any appliance using electrical power supply that has reached its end of life' [3], comprises a wide range of appliances, which vary considerably in material composition and require different technologies for treatment. Table 1 gives an overview of the composition of e-waste by category. In this text, five categories are used:

- Large appliances (LA) such as washing machines or dishwashers with a high proportion of metals 
Table 1 Material composition of e-waste by category (data for LA, C\&F, FT and CRT from [4]; data for LCD monitors and LCD TV from [5])

\begin{tabular}{|c|c|c|c|c|c|c|}
\hline & \multirow[b]{2}{*}{$\begin{array}{l}\mathrm{LA} \\
(\%)\end{array}$} & \multirow[b]{2}{*}{$\begin{array}{l}\mathrm{C} \& \mathrm{~F} \\
(\%)\end{array}$} & \multicolumn{3}{|c|}{ Screens } & \multirow[b]{2}{*}{$\begin{array}{l}\text { FT } \\
(\%)\end{array}$} \\
\hline & & & $\begin{array}{l}\text { CRT } \\
(\%)\end{array}$ & $\begin{array}{l}\text { LCD monitor } \\
(\%)\end{array}$ & $\begin{array}{l}\text { LCD TV } \\
(\%)\end{array}$ & \\
\hline $\begin{array}{l}\text { Hazardous } \\
\text { components }\end{array}$ & 0.1 & 0.5 & 0.2 & 0.3 & 1.1 & 1.7 \\
\hline Iron and steel & 55.9 & 66.3 & 5.3 & 40.9 & 53.5 & 1.9 \\
\hline Aluminium & 1.7 & 3.3 & 1.6 & 5.2 & 0.6 & 5.6 \\
\hline Copper & 2.2 & 2.3 & & & & 1.8 \\
\hline Cables & 1.8 & 0.3 & 1.8 & 1.1 & 0.9 & \\
\hline Plastics & 12.7 & 25.3 & 12.7 & 12.7 & 25.3 & 1.7 \\
\hline $\begin{array}{l}\text { Printed circuit } \\
\text { boards }\end{array}$ & 0.1 & & 9.5 & 8.1 & 6.1 & 0.9 \\
\hline Compounds & & & 6.4 & & & \\
\hline Other materials & 25.5 & 1.9 & 62.2 & 8.1 & 7.7 & 86.4 \\
\hline Total & 100 & 100 & 100 & 100 & 100 & 100 \\
\hline
\end{tabular}

$L A$ large appliances, $C \& F$ cooling and freezing equipment, $C R T$ cathode ray tube devices (TVs and monitors), $L C D$ monitors liquid crystal monitors, $L C D T V$ liquid crystal television sets, $F T$ fluorescent tubes

- Cooling and freezing equipment $(\mathrm{C} \& \mathrm{~F})$ with refrigerators, freezers and air condition equipment where CFC-containing cooling agents and CFCs in the insulation pose specific challenges during the treatment

- Screens with CRT monitors or TV sets with more than 50\% glass (here listed as other materials) and LCD screens with higher proportions of plastics and backlights partly containing $\mathrm{Hg}$

- Fluorescent tubes (FT), where the majority of material is glass and the $\mathrm{Hg}$ content requires specific treatment

- Small appliances (SA) with several subcategories

In Table 2, more details on small appliances (SA) are given. In this context, SA are defined as all types of e-waste smaller than $50 \mathrm{~cm}$ along their longest edge, excluding cooling and freezing equipment, lamps and screens. SA are regarded as the most valuable part of the e-waste stream, containing IT as well as consumer electronics with a higher content of non-ferrous and precious metals. Printed circuit boards contain high concentrations of copper and higher concentrations of precious metals than any other category, which are mainly found in information and communication technology equipment (ICT), e.g. computers, mobile phones, printers, etc., and consumer electronics, such as audio equipment, SAT receivers, etc.

Hazardous components in Tables 1 and 2 summarise all components containing hazardous substances which are listed in Annex VII of the WEEE II Directive 2012/ 19/EU [7]. The list of hazardous components includes batteries, capacitors (all capacitors containing polychlorinated biphenyls and electrolyte capacitors larger than $25 \mathrm{~mm}$ ), printed circuit boards (of mobile phones generally or those larger than 
Table 2 Material composition of small appliances (SA) by subcategories [6]

\begin{tabular}{l|l|l|l|l|l|l}
\hline & $\mathrm{SA}(\%)$ & $1 \mathrm{C}(\%)$ & $2(\%)$ & $3 \mathrm{~A}(\%)$ & $4 \mathrm{~A}(\%)$ & $5-9(\%)$ \\
\hline Hazardous components & 0.9 & 0.6 & 0.4 & 1.3 & 0.9 & 0.9 \\
\hline Iron and steel & 37.6 & 71.1 & 15.9 & 49.6 & 37.2 & 32.5 \\
\hline Aluminium & 1.7 & 0.8 & 2.0 & 1.9 & 2.1 & \\
\hline Copper & 1.0 & 4.1 & 0.0 & 0.9 & 2.8 & \\
\hline Cables & 4.1 & 0.9 & 6.5 & 2.8 & 1.3 & 8.5 \\
\hline Plastics & 29.8 & 12.7 & 45.7 & 31.3 & 21.3 & 10.3 \\
\hline Printed circuit boards & 5.4 & 0.2 & 0.1 & 9.6 & 10.1 & 0.4 \\
\hline Compounds & 11.5 & 5.9 & 26.3 & 2.0 & 6.0 & 19.1 \\
\hline Other materials & 7.9 & 3.7 & 3.1 & 0.5 & 18.3 & 28.3 \\
\hline Total & 100 & 100 & 100 & 100 & 100 & 100 \\
\hline
\end{tabular}

Subcategories: $1 C$ small household equipment (large), 2 small domestic appliances, $3 \mathrm{~A}$ information and communication equipment (without screen), $4 \mathrm{~A}$ consumer electronics (without screen), 5-9 other small equipment

$10 \mathrm{~cm}^{2}$ ), toner cartridges, liquid crystal displays (larger than $100 \mathrm{~cm}^{2}$ and those back-lighted with gas discharge lamps), mercury-containing components such as switches or backlighting lamps, asbestos-containing components, components containing refractory ceramic fibres, components containing radioactive substances, plastic-containing brominated flame retardants, cathode ray tubes and halogenated coolants.

\section{Collection}

\subsection{E-Waste Collection in Europe}

In Europe, most collection schemes for e-waste from households have been set up as part of existing municipal collection schemes for recyclables and hazardous household waste and additional take-back schemes by retailers. In some countries (e.g. Belgium, France), take-back through reuse centres plays an important role, while in others, scrap dealers are a relevant collection avenue (e.g. in Greece).

Quantities of e-waste generated vary considerable between wealthy countries (such as Austria, Belgium, France, Germany and Sweden with more than $20 \mathrm{~kg} / \mathrm{cap} /$ year) and less affluent ones. Collection quantities range between 4 and $17 \mathrm{~kg} / \mathrm{cap} /$ year, depending on the development stage of the collection schemes. According to Baldé et al. [8], EU member states on average collected 3.2 from $9 \mathrm{mt}$ generated in 2014 , representing an average collection rate of 36\%. Most successful collection schemes can be found in Scandinavia (Sweden), where $17.5 \mathrm{~kg} / \mathrm{cap} / \mathrm{year}$ were collected in 2012. More details on the generation and collection rates of e-waste in selected EU member states are shown in Table 3. 
Table 3 E-waste quantities generated in 2014 and collected in selected EU member states [8]

\begin{tabular}{l|l|l|l}
\hline & E-waste generated (kg/cap/year) & E-waste collected $(\mathrm{kg} /$ cap/year) & Year \\
\hline Austria & 22.0 & 9.0 & 2012 \\
\hline Belgium & 21.4 & 10.3 & 2012 \\
\hline Bulgaria & 10.7 & 5.3 & 2012 \\
\hline France & 22.1 & 6.8 & 2010 \\
\hline Germany & 21.6 & 8.5 & 2012 \\
\hline Greece & 15.1 & 4.2 & 2010 \\
\hline Italy & 17.6 & 3.8 & 2012 \\
\hline Sweden & 22.2 & 17.5 & 2012 \\
\hline
\end{tabular}

In western European member states, the initial collection target from the WEEE I Directive [1] of $4 \mathrm{~kg} / \mathrm{cap} /$ year is met easily, while for new member states, it is still a challenge. Under the WEEE II Directive [7], higher collection targets, i.e. $65 \%$ of the quantity put on the market or alternatively $85 \%$ of e-waste in waste streams, are mandatory from 2019 onward. To cope with this, several cities and regions in Europe have started to identify options to raise the collection efficiency. Besides conventional take-back at municipal collection sites, the following collection routes have been tested:

- Kerbside collection at multifamily dwellings as a convenient option for residents of densely populated areas. A collection trial at a multifamily dwelling in Vienna showed collection rates of SA of $0.4-1.1 \mathrm{~kg} / \mathrm{cap} / \mathrm{year}$, and kerbside collection with containers in Copenhagen reached $1.33 \mathrm{~kg} / \mathrm{cap} /$ year [9].

- Another approach is to instal container collection in public places. Case studies have been found for Sweden and Germany, where collection rates for SA range from 0.04 to $0.84 \mathrm{~kg} / \mathrm{cap} /$ year (cf. [10]). However, this unmanned and uncontrolled way of collection is increasingly considered unsafe following a series of fire incidents at e-waste storage and recycling facilities caused by selfigniting lithium ion batteries.

- Intensified collection of SA at retail outlets. Two case studies from Sweden and Germany show low collection rates (cf. [10]).

The challenge in e-waste collection in Europe in the coming years will be to identify ways to intensify collection by offering a better collection service to households and providing more information to motivate citizens for collection. Further, illegal exports from Europe will lead to a loss of resources for the European industry. In Germany, the amount of illegal exports in 2008 was estimated at $155,000 \mathrm{t}$ [11]. These exports were heavily criticised and are now subject to more detailed regulations in Annex VI of the WEEE II Directive [7], which define the circumstances under which exports may take place. 


\subsection{E-Waste Collection in China}

The generation rate of e-waste for China is estimated at $6.0 \mathrm{mt} / \mathrm{year}$ (2014), and the collection rate for 2013 is given at $1.3 \mathrm{mt}$ [8]. Today, informal structures dominate e-waste collection and take-back, as they have wide urban collection networks, offer high reimbursements to consumers and have access to a bigger and cheaper labour force compared to formal collection channels. These characteristics have already been identified in the first pilot trials with formal collection schemes in which attaining sufficiently high rates in e-waste collection posed the major problem, as collection systems were either controlled or strongly permeated by informal actors [12-15]. The Chinese government has been learning from these initial difficulties: the 'Old for New' scheme (OfN) tried to make the formal collection system more attractive in two ways. On the one hand, electronics retailers and other formal take-back entities were given subsidies to offer incentives to consumers to return their e-waste to formal channels. On the other hand, recyclers also received comparatively high subsidies, enabling them to successfully compete with informal collection systems [16-18].

The results in terms of collection rates in the OfN programme are shown in Table 4. Although the OfN scheme has achieved respectable collection rates $(0.4-2.1 \mathrm{~kg} / \mathrm{cap} / \mathrm{year})$, the persistent problem for the formal system remained the collection costs, which primarily originate as a consequence of competition with the informal sector. Compared to private enterprises in the government pilots, the informal sector has lower personnel costs related to collection and recycling, which allows it to pay higher prices for e-waste originating from households and companies [20].

Table 4 Collection rates in the 'old for new' pilot scheme [19]

\begin{tabular}{l|l|l|l|l|l|l|l}
\hline & Inhabitants & $\begin{array}{l}\text { TV sets } \\
\text { (kg/cap/ }\end{array}$ & $\begin{array}{l}\text { Refrigerators } \\
\text { (kg/cap/year) }\end{array}$ & $\begin{array}{l}\text { Washing } \\
\text { machines } \\
\text { (kg/cap/ } \\
\text { year) }\end{array}$ & $\begin{array}{l}\text { Air } \\
\text { conditioners } \\
\text { (kg/cap/ } \\
\text { year) }\end{array}$ & $\begin{array}{l}\text { Computers } \\
\text { (kg/cap/ } \\
\text { year) }\end{array}$ & $\begin{array}{l}\text { Total } \\
\text { (kg/cap/ } \\
\text { year) }\end{array}$ \\
\hline Beijing & 19,600 & 0.64 & 0.16 & 0.73 & 0.05 & 0.04 & 1.62 \\
\hline Tianjin & 12,280 & 0.50 & 0.08 & 0.42 & 0.02 & 0.02 & 1.04 \\
\hline Shanghai & 23,019 & 1.62 & 0.07 & 0.33 & 0.02 & 0.03 & 2.08 \\
\hline $\begin{array}{l}\text { Jiangsu } \\
\text { province }\end{array}$ & 77,250 & 0.67 & 0.04 & 0.27 & 0.01 & 0.01 & 1.00 \\
\hline $\begin{array}{l}\text { Zhejiang } \\
\text { province }\end{array}$ & 51,800 & 0.54 & 0.03 & 0.12 & 0.01 & 0.03 & 0.74 \\
\hline Fuzhou & 3,380 & 0.74 & 0.03 & 0.21 & 0.01 & 0.01 & 0.99 \\
\hline $\begin{array}{l}\text { Shandong } \\
\text { province }\end{array}$ & 95,790 & 0.30 & 0.03 & 0.13 & 0.00 & 0.01 & 0.47 \\
\hline Changsha & 7,044 & 0.55 & 0.05 & 0.25 & 0.02 & 0.00 & 0.86 \\
\hline Guangdong & 104,300 & 0.19 & 0.03 & 0.18 & 0.03 & 0.00 & 0.44 \\
\hline
\end{tabular}


In fact, the informal segment still dominates the collection of e-waste from households. The entangled relationship between urban residents and informal collectors has been stated in previous research as a major reason for this development (compare [12, 17, 20,21]) and may in essence originate in the societal value structure of urban Chinese society: Household waste, including e-waste, is widely perceived as a valuable commodity and thus is expected to be exchanged for money. Unsurprisingly, residents thus prefer informal collection systems for e-waste, e.g. $71 \%$ in Beijing [21], since they offer pecuniary reimbursements and convenient doorstep collection services. In fact, many major Chinese cities exhibit high amounts of informally collected e-waste from households (see Table 4) that by far exceed formally collected or received amounts.

The challenge in e-waste collection in China is the fact that informal collection is by far the most convenient option for residents: collectors pick up e-waste (and other recyclables) at the household and even pay some money to receive it. As residents do not need to take any action, they prefer this collection path to others which will require them to bring e-waste to collection points. Informal collectors work under unregulated labour conditions, often lacking social security and social acceptance. This needs to be seen in the wider context of informal work where waste collection and recycling represent only a smaller sector. For more details on informal work in China, see Baum [22].

\subsection{E-Waste Collection in Vietnam}

Vietnam, a country with about $93 \mathrm{~m}$ inhabitants, has a generation rate estimated at $2.6 \mathrm{~kg} / \mathrm{cap} /$ year, leading to a national waste generation rate of $0.23 \mathrm{mt} / \mathrm{year}$; however, the data for collection rates are not available [23]. As no formal collection scheme for e-waste exists, collection takes place through informal collectors. There are thousands of peddlers who collect disposed appliances from end users and sell them to service shops or traders. They are seen as 'saviours' for e-waste, achieving high collections rates [23]. The peddlers use motorcycles, bicycles or even bamboo frames on their shoulders, moving from house to house to buy e-waste (and other recyclable waste) and bring it to the places where those items can be sold at a higher price. This informal e-waste handling system is very active and successful [24].

Challenges for e-waste collection in Vietnam are both the lack of a formal collection scheme and the labour conditions of informal collectors.

\section{Treatment}

\subsection{Treatment in Europe}

The treatment process for e-waste typically includes dismantling, processing and end processing. Dismantling is the first step to separate hazardous components as 
well as valuable components. In the subsequent processing, materials are fragmentised to liberate the materials from compounds and separated. End processing means those processes where the materials end up, e.g. steel scrap ending up in steel mills to be re-melted, plastic being re-granulated after sorting and cleaning or the disposal of hazardous components at hazardous waste treatment facilities. The processes applied vary considerably by product category:

For large appliances, e.g. washing machines, dishwashers, etc., the treatment starts with the removal of hazardous components by dismantling (capacitor, $\mathrm{Hg}$ components), followed by mechanical processing using shredder and separation technologies (magnetic separation, eddy current separator, etc.).

Cooling and freezing equipment, e.g. refrigerators and freezers, is processed at dedicated installations to remove CFCs from the cooling circle; in a next step, CFCs are removed from insulation using encapsulated cutting mills with pressure, followed by mechanical processing. It is important to note that CFCs are increasingly being replaced by other cooling agents; thus a future challenge for the recycling industry will be the identification of equipment that contains CFCs.

Lighting equipment, i.e. fluorescent lamps and compact fluorescent lamps, are treated by crushing or cutting, and this needs to take place in encapsulated machinery to avoid the emission of $\mathrm{Hg}$ vapour. The output materials represent low value.

For screens, different technologies are used: CRT monitors and CRT TV sets go to dismantling and specific treatment to separate the glass. For flat screens, there are new technologies for LCD treatment, as these partly contain fluorescent tubes containing $\mathrm{Hg}$.

Small appliances undergo dismantling or mechanical breakup and sorting for hazardous components and valuable materials, followed by mechanical processing. The output materials represent high value, specifically from non-ferrous materials and printed circuit boards (PCBs). Dismantling is conducted by manually dismantling and separating hazardous as well as valuable components. Driven by the high costs of manual labour in Europe, mechanical processing has been developed to replace manual dismantling as much as possible. Here, technologies to break up appliances in a slowly rotating drum ('smasher') or to cut up SA ('cross-flow shredder'), both are followed by a sorting process for the removal of hazardous and valuable components. For the subsequent processing by crushing and separation, a wide spectrum of technologies like hammer mills, magnetic separation, sieves, eddy current separators and other classifiers have been installed and improved in the European recycling industry. Thoroughly applied, these technologies produce high-quality secondary products, mainly metal concentrates as input to metal mills and plastics. Hazardous components and materials that have not been recycled are sent to disposal by incineration, landfilling and hazardous waste treatment. For details of the treatment processes, see Cui and Forssberg [25], Salhofer and Gabriel [26] and others. Table 5 gives an overview of the separation technologies applied mainly for the treatment of end-of-life vehicles, and most of these processes are also applied for e-waste. The effect of dismantling on the separation of hazardous components was analysed for e-waste treatment plants in Austria [28]. Modelling the potential content of components containing hazardous 
Table 5 Processes for the separation of materials after fragmentation [27]

\begin{tabular}{|c|c|c|c|c|c|c|c|}
\hline Separation techniques & Argonne & Galloo & $\begin{array}{l}\text { MBA- } \\
\text { polymers }\end{array}$ & $\begin{array}{l}\text { Salyp } \\
\text { process }\end{array}$ & Stena & $\begin{array}{l}\mathrm{R}- \\
\text { plus }\end{array}$ & $\begin{array}{l}\text { VW- } \\
\text { Sicon }\end{array}$ \\
\hline Air classification & $\mathrm{X}$ & $\mathrm{X}$ & $\mathrm{X}$ & $\mathrm{X}$ & $\mathrm{X}$ & $\mathrm{X}$ & $\mathrm{X}$ \\
\hline Magnetic separation & $\mathrm{X}$ & $\mathrm{X}$ & $\mathrm{X}$ & $\mathrm{X}$ & $\mathrm{X}$ & $\mathrm{X}$ & $\mathrm{X}$ \\
\hline Eddy current separation & $\mathrm{X}$ & $\mathrm{X}$ & $\mathrm{X}$ & $\mathrm{X}$ & $\mathrm{X}$ & & $\mathrm{X}$ \\
\hline Screening & & $X$ & & $\mathrm{X}$ & $\mathrm{X}$ & $\mathrm{X}$ & $\mathrm{X}$ \\
\hline Trommel separation & $\mathrm{X}$ & $\mathrm{X}$ & & $\mathrm{X}$ & $\mathrm{X}$ & & $\mathrm{X}$ \\
\hline Optical sorting & & & & $\mathrm{X}$ & & & $\mathrm{X}$ \\
\hline Manual sorting & & & & & $\mathrm{X}$ & & \\
\hline Drying & & & & & & $\mathrm{X}$ & \\
\hline Float/sink separation & & $\mathrm{X}$ & & $\mathrm{X}$ & $\mathrm{X}$ & & $\mathrm{X}$ \\
\hline Froth flotation & $\mathrm{X}$ & & & & & & \\
\hline $\begin{array}{l}\text { Thermo-mechanical } \\
\text { sorting }\end{array}$ & & & & $\mathrm{X}$ & & & \\
\hline Wet grinding & & & $\mathrm{X}$ & & & & \\
\hline Hydrocyclone & & & $\mathrm{X}$ & & & & \\
\hline $\begin{array}{l}\text { Static, hydrodynamic } \\
\text { separation tanks }\end{array}$ & & $\mathrm{X}$ & & & & & \\
\hline Heavy media separation & & & & & $\mathrm{X}$ & & \\
\hline
\end{tabular}

substances in the input material and comparing them to the output of the plants led to removal rates for selected components of 50-70\%, demonstrating the limitation of manual dismantling on a case study basis.

A typical treatment sequence for e-waste in Europe, based on Wäger et al. [29], comprises the following steps: after collection and transport, the end-of-life products reach the recycling facility, where sorting, dismantling and mechanical processing take place. The output materials are either ready for end processing (e.g. steel and aluminium scrap) or undergo further treatment steps (e.g. mixed materials, cables, plastics, PCBs and CRTs). In the subsequent treatment, compound materials ('metal and/or plastic mix') such as motors, coils, etc., and cables are further processed mechanically to separate different materials (metals from plastics and non-ferrous metals from ferrous metals). This task is often assigned to specialised treatment companies. CRT screens are separated into front and neck glass, and the fluorescent powder is removed. Batteries from dismantling are sent to specialised battery recycling facilities. Other waste (wood from cabinets, insulation materials, hazardous materials, etc.) is sent to disposal (see Fig. 1).

Printed circuit boards harvested from the dismantling are traded and sent to specialised metallurgic treatment facilities. Within Europe there are three plants (Aurubis, Boliden, Umicore) which apply different smelting processes, followed by other steps such as hydrometallurgy. These special smelters achieve high recycling rates, for example, Umicore claims recycling rates for precious metals of more than 95\% [30]. Plastics from dismantling and - to a larger extent - from mechanical processing undergo sorting (sensor based sorting, heavy media separators, among 


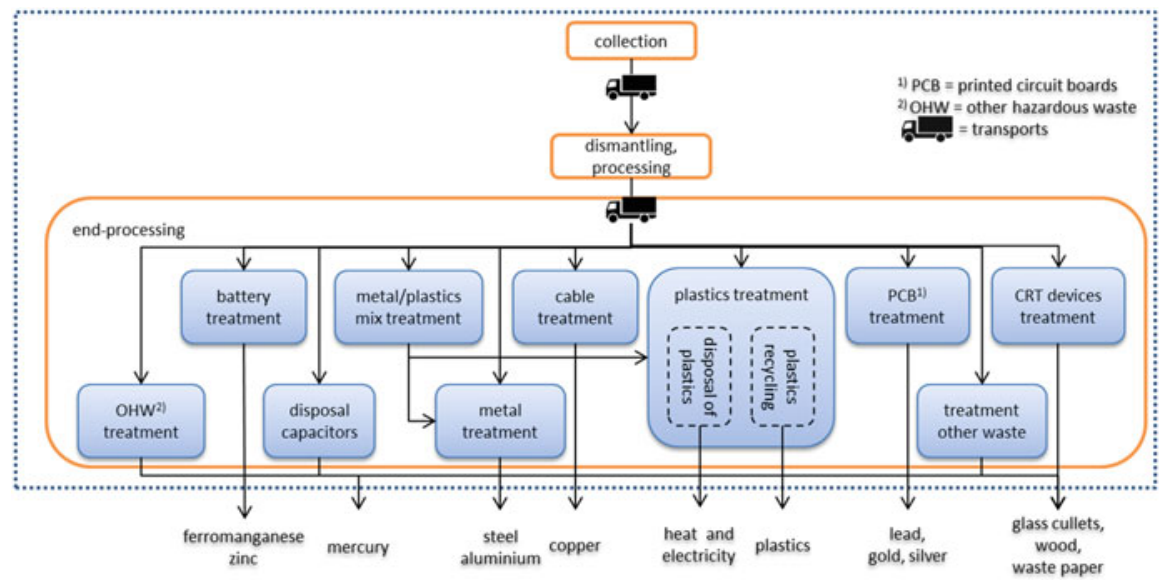

Fig. 1 E-waste treatment technologies in Europe (schematically, based on [29])

others), and then go into materials recycling, or are incinerated or disposed of in landfills, respectively.

Some challenges in the future will be to level the standards for technology as well as for monitoring in the EU member states. As a directive, like the European WEEE II Directive [7], it sets only a framework. National implementation will vary and produce unfair competition, favouring low-cost technology with lower material yields.

\subsection{Treatment in China}

From the 1980s onward, China has imported increasing amounts of e-waste from the USA, Europe and other regions for recycling (cf. [31]). The driving force was the growing demand for resources in a rapidly growing production industry, which could cover the material demand partly through recycling. In some areas, most prominently in Guiyu (Guangdong province), large capacities for e-waste treatment have been developed. In Guiyu at its peak period in 2011, up to 150,000 people worked in recycling [32]. Geeraerts et al. [33] estimate the import quantity a high as $8 \mathrm{mt} /$ year. Without regulations, neglecting the partly hazardous nature of the material and following the principle of lowest cost, highly polluting practices are established. Sepúlveda et al. [34] describe typical e-waste treatment techniques and processes in China and India. These techniques include the open burning of PCBs, cables and plastics and the burning of PCBs to separate the components of recovered solder and leaching and the amalgamation of PCBs to recover precious metals. The emissions from these processes include, among others, lead, PBDEs, dioxins and furans and are found in several outputs such as particulate matter, fumes, ashes and liquid emissions (effluents) from dumping activities, as well as from 
hydrometallurgical processes (leaching, amalgamation). High concentrations have been identified in air pollution, solid residues, dust and soil, as well as in water and sediments. The values exceed comparison values, e.g. for lead in the WHO Drinking Water Guidelines [35], by several orders of magnitude and show the pollution in the environment as well as health and safety threats for workers and residents.

Along with the establishment of recent legislation for the treatment of e-waste (cf. [36]) and supported by a subsidies program, large capacities for e-waste treatment have been developed. By mid-2015, 106 recycling plants were included in the China e-waste funding scheme, and treatment has reached a volume of $1,458 \mathrm{mt}$ in 2014 [37], compared to an estimated generation of $6.0 \mathrm{mt}$ [8]. In the course of the last 3 years (2012-2015), 12 recycling facilities situated along China's East coast have been visited [19]. Eleven of these facilities mainly dismantle appliances, and some have subsequent treatment steps. Only one of these facilities focusses explicitly on the treatment of materials from dismantling, i.e. cables and PCBs.

Concerning the range of product types processed, 7 of the 11 dismantling facilities cover all 5 product types under regulation (CRT TV sets, refrigerators, air conditioners, PCs and washing machines), while the rest have capacity for some of the products. Two recyclers have established dismantling lines for additional products not covered by the regulations (LCD screens, toner cartridges). The dismantling process is undertaken manually, typically with the aid of conveyor belts, workstations with tools and boxes or shafts for the output materials for dismantling.

For treatment of CRT TV sets, the following steps are applied: After opening the housings and separating housing materials, metal frames, PCBs and cables, the glass body of the screen is split into the front and cone glass, in most cases with hot wire technology, and in one case, laser cutting technology was applied. Then fluorescent powder is sucked off.

In most cases, refrigerators and air conditioners undergo a two-stage treatment where in the first stage the coolant is extracted and in the second stage the body of the refrigerator is fragmentised in a closed system. In one case, only the second step is applied, i.e. refrigerators directly go into the shredder.

PCs as well as washing machines are dismantled manually. LCD screens (one plant only) are dismantled in an underpressurised cabin to avoid the accidental release of $\mathrm{Hg}$ from potentially broken backlight fluorescent lamps, and workers in the cabin wear appropriate safety equipment. After dismantling, the LCD panel is crushed in an enclosed machine. Toner cartridges (one plant only) are fragmentised mechanically, followed by a cleaning step where the toner dust is separated. The ferrous metals, non-ferrous metals and plastics are separated.

The processing of PCBs takes place in eight of the facilities (seven dismantling facilities and one specialist for cables and PCBs), and this treatment is done mechanically (fragmentising and separating materials) with the aim of recovering copper. Three recyclers reported to send the PCBs to mechanical recycling at a specialised plant. Only one recycler operated a hydro- and pyrometallurgic facility, 
which recovers, in addition to copper, gold and silver. The processes applied are stripping, electrolysis and a refinement of gold through a melting process.

Plastics from dismantling are partly sorted into plastic types and partly fragmentised to reduce the volume for transport into specialised plastic recyclers. No separation of plastics with brominated flame retardants was observed in the plants visited. Some e-waste recyclers use plastics from dismantling directly for the production of wood plastic compounds.

Figure 2 shows the input into recycling facilities in five provinces (Beijing, Hubei, Zhejiang, Jiangsu and Guangdong), where the above-mentioned recycling plants are located and which were visited as part of the REWIN project [38]. The figure shows the quick increase in treatment capacities from 2010 to 2014 and, secondly, the large proportion of TV sets (80-90\% of the mass input) compared to other types of appliances. It is obvious that TV sets are less attractive for informal recyclers compared to product types like PCs, refrigerators or air conditioners, as the latter have a higher share of ferrous, non-ferrous or - for PCs - precious metals.

The main challenge for the treatment of e-waste in China is the variable and partly lacking supply of input material for recycling facilities. Comparing e-waste generation and input to formal recycling facilities makes clear that a larger part of the e-waste still does not end up in the formal recycling industry but probably undergoes informal treatment practices. For the established formal recycling facilities, the processing of PCBs and plastics poses challenges, as PCBs are mainly processed mechanically, leading to a loss of precious metals, and plastics are typically not separated into materials containing (brominated) flame retardant and those free of flame retardants.

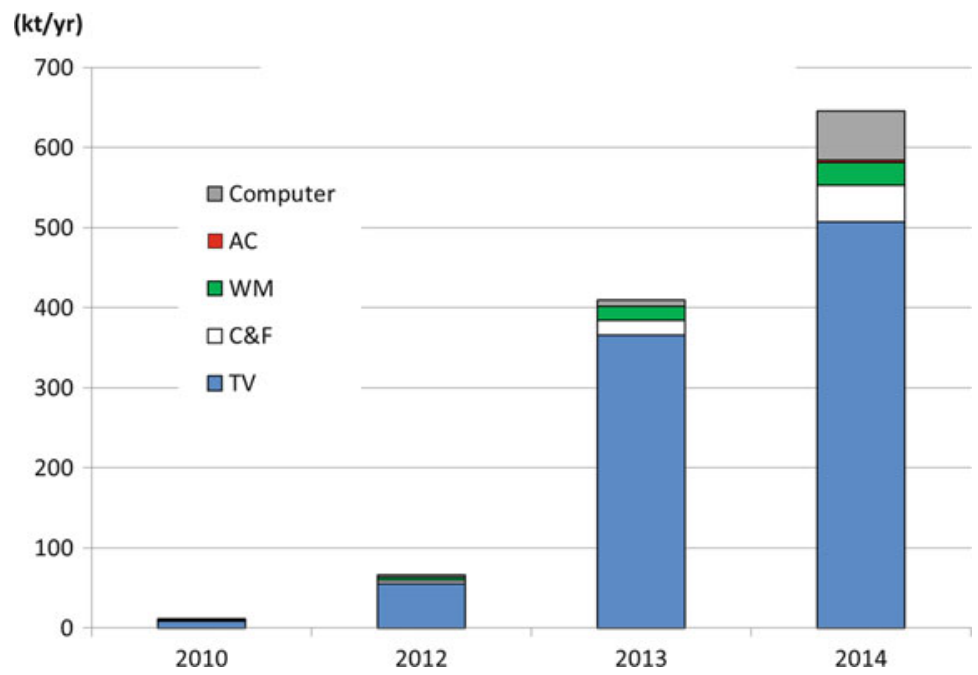

Fig. 2 Treatment quantities in five Chinese provinces 2010-2014 [38] 


\subsection{Treatment in Vietnam}

Besides recycling to recover materials, reuse and repair play an important role in the management of e-waste in Vietnam. After being collected, the appliances are classified by collectors, repairers and service shops. The appliances undergo a thorough repair or refurbishment process and then are sold in second-hand markets. The repair and service shops disassemble useable components for reuse, and only appliances which are impossible to repair or do not pay off the cost of the repair will be transferred to dismantling workshops. At those workshops, reusable parts (transistors, chips, parts) are collected for selling to repairers and service shops for part replacement during repair work.

The following step of dismantling is undertaken to separate materials and prepare them for further processing. In Vietnam, this step typically takes place at 'craft villages', which are villages with a profession different from agricultural activities, creating income for the habitants. Thus, craft villages play an important role in rural economic development, as they provide work for residents of neighbouring villages. Twenty seven percent of farm households earn income from both farming and other careers, while thirteen percent of rural households are professionally engaged in careers other than farming [39]. They have also attracted about ten million full-time workers, representing approximately $30 \%$ of workers in rural areas (cf. [40]). The e-waste treatment was counted for approximately 30 craft villages handling e-waste recycling out of 90 waste recycling villages, mainly in the north of Vietnam, from a total of more than 3,000 craft villages in Vietnam [23]. At those villages, e-waste is dismantled and sorted manually into components by workers working with no or with a low level of protective equipment. Workshops at e-waste dismantling craft villages have been specialised by types of appliances. For example, some workshops only buy and dismantle refrigerators and washing machines, some only collect CD and DVD players, and some are in charge of plastic collecting and grinding. After dismantling, the tradable parts are classified for further treatment or sale. Risky processes, like the open burning of copper wires to extract copper or the chipping and melting of mixed plastics, are widely used, and the residues from these processes are discharged into fields, riverbanks or ponds.

The current situation of e-waste treatment has led to many serious risks related to the environment and human health, not only of the workers at those workshops but also for residents living close to workshops. The analysis of Tue et al. [41] showed the accumulation of polychlorinated biphenyls and brominated flame retardants in breast milk from women living in e-waste recycling sites (Bui Dau in Hung Yen province) at very high levels of polybrominated diphenyl ethers and hexabromocyclododecanes. Tue et al. [42] found the polychlorinated biphenyl and brominated flame-retardant contaminants in indoor dust and air at informal e-waste recycling site to be significantly higher than in urban house dust. The soil near workshops and open burning places was contaminated by flame retardants from e-waste recycling (cf. [43]). Dioxins, originating from high-temperature processes in e-waste 
recycling, such as open burning of copper wires and plastic recycling process using conventional extruders [44], were concentrated.

It is difficult to estimate, monitor and record how much e-waste is transported to and processed at craft villages in Vietnam. The data on e-waste is rough, and based on estimates from interviews with people from craft villages, experts and traders in the field, it is impossible to clarify the situation with certainty. More details about processes applied in e-waste treatment in Vietnam can be found in Tran and Salhofer [23].

The main challenges are both the heavy environmental pollution from uncontrolled processes and health threats to workers and the residents of craft villages.

\section{Conclusions}

From the wide range of products covered, e-waste is one of the most complex waste streams. The properties of the different e-waste categories imply that a number of technologies are required to cover the whole range of products. The level of legislation and implementation varies significantly between regions and countries.

In Europe, e-waste management has been developed from existing structures in municipal waste management, mainly organised by municipalities. $3.2 \mathrm{mt}$ from a generation mass of $9 \mathrm{mt}$ were collected in 2014. The challenges are:

- To intensify collection and to confine illegal exports

- To establish uniform technical and monitoring standards for treatment throughout EU member states

For a long time in China, the informal sector was dominated by both the collection and treatment of e-waste. After recent legislation and public funding, large (formal) treatment capacities have been developed, while, lacking formal alternatives, collection is still dominated by the informal sector. From a generated mass of $6.0 \mathrm{mt}$, in 2013, $1.3 \mathrm{mt}$ were collected for recycling. Challenges are:

- The need to improve labour conditions and the social security of informal collectors

- The lack of input to recycling facilities due to the strong competition with the informal recycling sector

- Technology for the treatment of PCBs and plastics

In Vietnam, both collection and treatment are in the hands of the informal sector; unsafe practices and environmental hazards are consequences. Challenges are:

- To improve the labour conditions of informal collectors

- Environmental pollution as well as health threats from uncontrolled processes 


\section{References}

1. EU (2002) Directive 2002/96/EC of the European Parliament and of the Council of 27 January 2003 on waste electrical and electronic equipment (WEEE). http://eur-lex.europa.eu/legalcontent/EN/TXT/?uri=CELEX:32002L0096. Accessed 7 Jan 2017

2. OECD (2016) Extended producer responsibility: updated guidance for efficient waste management. OECD Publishing, Paris. doi:10.1787/9789264256385-en

3. OECD (2001) Extended producer responsibility: a guidance manual for governments. OECD Publishing, Paris. doi:10.1787/9789264189867-en

4. Huisman J, Magalini F, Kuehr R, Maurer C, Ogilvoe S, Poll J, Delgado C, Artim E, Szlezak J, Stevels A (2007) Review of Directive 2002/96 on Waste Electrical and Electronic Equipment (WEEE). Final report. http://ec.europa.eu/environment/waste/weee/pdf/final_rep_unu.pdf

5. Salhofer S, Spitzbart M, Maurer K (2012) Recycling of flat screens as a new challenge in WEEE recycling. Waste Resour Manage 165:37-43

6. Salhofer S, Spitzbart M (2009) Modelling of mechanical treatment of WEEE. In: Proceedings of the 3rd BOKU waste conference, Vienna, pp 143-150

7. EU (2012) Directive 2012/19/EU on waste electrical and electronic equipment. http://eur-lex. europa.eu/legal-content/EN/TXT/?uri=CELEX:32012L0019. Accessed 7 Jan 2017

8. Baldé CP, Wang F, Kuehr R, Huisman J (2015) The global e-waste monitor - 2014. United Nations University, IAS - SCYCLE, Bonn, Germany. http://i.unu.edu/media/unu.edu/news/ 52624/UNU-1stGlobal-E-Waste-Monitor-2014-small.pdf

9. Borregaard J (2013) Experiences from WEEE collection trials in Copenhagen. Presentation at ISWA Beacon conference, Düsseldorf, Nov 2013

10. Salhofer S (2014) Small, but powerful - why we should put more emphasis on the collection of small WEEE. In: Proceedings SUM 2014, second symposium on urban mining, Bergamo, Italy

11. Sander K, Schilling S (2010) Optimierung der Steuerung und Kontrolle grenzüberschreitender Stoffströme bei Elektroaltgeräten/Elektroschrott. Umweltbundesamt, Deutschalnd. http://www. umweltbundesamt.de/publikationen/optimierung-steuerung-kontrolle. Accessed 7 Jan 17

12. Chung SS, Zhang C (2011) An evaluation of legislative measures on electrical and electronic waste in the People's Republic of China. Waste Manag 31:2638-2646

13. Hicks C, Dietmar R, Eugster M (2005) The recycling and disposal of electrical and electronic waste in China - legislative and market responses. Environ Impact Assess Rev 25:459-471

14. Qu Y, Zhu Q, Sarkis J, Geng Y, Zhong Y (2013) A review of developing an e-waste collection system in Dalian. J Clean Prod 52:176-184

15. Yu J, Williams E, Ju M, Shao C (2010) Managing WEEE in China: policies, pilot projects and alternative approaches. Resour Conserv Recycl 54:991-999

16. Liu D, Shen Y (2012) Second report of a report series on the development trend of the renewable resource industry: report on the development trend of the WEEE industry (in Chinese). Internal company report, Beijing, pp 2-21

17. Wang F, Kuehr R, Ahlquist D, Li J (2013) E-waste in China: a country report. Step green paper series 10-47. http://isp.unu.edu/publications/scycle/files/ewaste-in-china.pdf

18. Zhong W (2010) WEEE collection management process and legislative institutional build-up (in Chinese). Policy Innov Stud 3:41-56

19. Salhofer S, Steuer B, Ramusch R, Beigl P (2016) WEEE management in Europe and China - a comparison. Waste Manag 57:27-35

20. Yang J, Lu B, Xu C (2008) WEEE flow and mitigating measures in China. Waste Manag 28 (2008):1589-1597

21. Wang Z, Zhang B, Yin J, Zhang X (2011) Willingness and behavior towards WEEE recycling for residents in Beijing city. Chin J Cleaner Prod 19:977-984

22. Baum J (2011) Background, basic concepts and overview on circular economy in China and Europe. In: Weigelin-Schwiedrzik S (ed) Re-sourcing in China: standards for circular economy - comparing China and the EU. Project report. Jubilee Fund of the Austrian Central Bank Project No. 13987, Vienna 
23. Tran CD, Salhofer S (2016) Analysis of recycling structures for e-waste in Vietnam. J Mater Sci Waste Manage 2016:1-17

24. Duc-Quang N, Yamasue E, Okumura H, Ishihara KN (2006) Wastes of electronic and electric equipment (WEEE) recycling system in Vietnam: a case study on copper recycling. In: Proceedings of the second joint international conference on Sustainable Energy and Environment (SEE 2006), vol 2, Bangkok, Thailand

25. Cui J, Forssberg E (2003) Mechanical recycling of waste electric and electronic equipment: a review. J Hazard Mater B99:243-263

26. Salhofer S, Gabriel R (2000) Mechanical processing or co-firing? Treatment of end-of-life electrical and electronic equipment from a waste management point of view. In: Proceedings of electronics goes green, Berlin, Germany

27. Vermeulen I, Van Caneghem J, Block C, Baeyens J, Vandercasteele C (2011) Automotive shredder residue (ASR): reviewing its production from end-of-life vehicles (ELVs) and its recycling, energy or chemicals valorisation. J Hazard Mater 190:8-27

28. Salhofer S, Tesar M (2011) Assessment of removal of components containing hazardous substances from small WEEE in Austria. J Hazard Mater 186:1481-1488

29. Wäger PA, Hischier R, Eugster M (2011) Environmental impacts of the Swiss collection and recovery system for waste electrical and electronic equipment (WEEE): a follow up. Waste Manag 409:1746-1756

30. Hagelueken C (2012) Recycling the platinum group metals: a European perspective. Platin Met Rev 56:29-35

31. Steuer B (2016) What institutional dynamics guide waste electrical and electronic equipment refurbishment and reuse in urban China? Recycling 1:286-310. doi:10.3390/recycling1020286

32. Steuer B (2015) Informelle EAG Behandlung im südchinesischen Guiyu - eine Feldstudie. Presentation at University of Natural Resources and Life Sciences, Vienna, 29 Oct 2015

33. Geeraerts K, Illes A, Schweizer JP (2015) Illegal shipment of e-waste from the EU. A case study on illegal e-waste export from EU to China. A study compiled as part of the EFFACE project. http://efface.eu/. Accessed 7 Jan 2017

34. Sepúlveda A, Schluep M, Renaud F, Streicher M, Kuehr R, Hagelueken C, Gerecke AC (2010) A review of the environmental fate and effects of hazardous substances released from electrical and electronic equipment during recycling: examples from China and India. Environ Impact Assess Rev 30:28-41

35. WHO (2011) Guidelines for drinking-water quality, 4th edn. World Health Organisation. http://www.who.int/water_sanitation_health/publications/2011/dwq_guidelines/en/. Accessed 7 Jan 17

36. Zeng X, Li J, Stevels A, Liu L (2013) Perspective of electronic waste management in China based on a legislation comparison between China and the EU. Waste Manage J Cleaner Prod $51: 80-87$

37. Hu H (2015) Policy and development thinking of electronic waste management. Presentation at the Shanghai IE Expo Summit Forum, 7 May 2015

38. Zhang M, Hou Q, Luo Q, Wu Y, Deng C, Steuer B (2015) WEEE recycling rates in REWIN target provinces - progress report 2012-2015. REWIN Project report 2015. http://www.rewinchina.net. Accessed 7 Jan 17

39. URENCO (2007) The development of E-waste inventory in Vietnam. Urban Environment One Member State-Owner Limited Company, Hanoi, Vietnam

40. MONORE (2011) Vietnam national environment report. Ministry of Natural Resource and Environment, Vietnam. http://archive.basel.int/techmatters/e_wastes/E-waste\%20Inventory\% 20in\%20Vietnam.pdf

41. Tue NM, Sudaryanto A, Minh TB, Isobe T, Takahashi S, Viet PH, Tanabe S (2010) Accumulation of polychlorinated biphenyls and brominated flame retardants in breast milk from women living in Vietnamese e-waste recycling sites. Sci Total Environ 408:2155-2162

42. Tue NM, Takahashi S, Suzuki G, Isobe T, Viet PH, Kobara Y, Seike N, Zhang G, Sudaryanto A, Tanabe S (2013) Contamination of indoor dust and air by polychlorinated 
biphenyls and brominated flame retardants and relevance of non-dietary exposure in Vietnamese informal e-waste recycling sites. Environ Int 51:160-167

43. Someya M, Suzuki G, Ionas AC, Tue NM, Xu F, Matsukami H, Covaci A, Tuyen LH, Viet PH, Takahashi S, Tanabe S, Takigami H (2015) Occurrence of emerging flame retardants from e-waste recycling activities in the northern part of Vietnam. Emerging Contam 2:58-65

44. Tue NM, Takahashi S, Subramanian A, Sakai S, Tanabe S (2013) Environmental contamination and human exposure to dioxin-related compounds in e-waste recycling sites of developing countries. Environ Sci: Processes Impacts 15:1326-1331 